\title{
TINJAUAN METODE PEMBAYARAN KARTU TOL ELEKTRONIK (LOKASI DI GERBANG TOL BANYUMANIK, JALAN TOL SEMARANG-SOLO)
}

\author{
${ }^{1}$ Seno Suharyo, ${ }^{2}$ Wardana Galih Pamungkas, ${ }^{3}$.Diah Rahmawati \\ 1,2,3. Fakultas Teknik, Universitas Semarang, Jl. Soekarno-Hatta Semarang \\ Email: ssuharyo@yahoo.com
}

\begin{abstract}
ABSTRAK
Jalan tol saat ini memiliki peran yang penting dalam mengefisienkan waktu tempuh perjalanan kendaraan roda 4 (empat) atau lebih dari satu tempat ke tempat yang lain. Sistem pembayaran tol juga ikut berkembang seiring bertambahnya jumlah kendaraan yang melewati jalan tol. Kartu tol elektronik menjadi satu-satunya metode pembayaran yang digunakan di semua gardu tol. Semua golongan kendaraan melakukan transaksi pembayaran tol menggunakan kartu tol elektronik. Mengenai efektifitas penggunaan kartu ini untuk semua jenis golongan kendaraan akan menjadi topik penelitian ini.

Metode penelitian yang digunakan adalah dengan survei lapangan dan melakukan wawancara. Hasil survei akan dianalisa untuk mengetahui tingkat kinerja pelayanan gardu tol.

Dari hasil rekapitulasi data sekunder pada data lalu lintas Gerbang Tol Banyumanik tanggal 5, $7,8,9,10,11$, dan 12 Mei 2018, total jumlah transaksi pembayaran menggunakan uang tunai sebesar 2.370 transaksi, sedangkan total jumlah transaksi pembayaran menggunakan kartu tol elektronik (e-toll card) sebesar 112.300 transaksi. Secara prosentase diperoleh perbandingannya sebesar $2 \%$ transaksi tunai berbanding $98 \%$ transaksi menggunakan kartu tol elektronik (e-toll card).

Untuk hasil survai diketahui tingkat kedatangan kendaraan arah keluar (exit) sebanyak 1985 kendaraan, tingkat pelayanan rata-rata kendaraan di gardu arah keluar (exit) sebesar 253 kendaraan/jam, dengan jumlah gardu pelayanan sebanyak 6 gardu. Rasio tingkat kedatangan dengan tingkat pelayanan $(\rho)$ adalah 1,3. Dengan nilai rasio tingkat kedatangan dibanding tingkat pelayanan gardu tol lebih besar dari $1(\rho \geq 1)$, maka dapat diartikan bahwa pada Gerbang Tol Banyumanik jalur keluar (exit) mengalami antrian yang cukup panjang. Salah satu alternatif cara untuk mengurangi panjang antrian adalah dengan mengalihkan sejumlah gardu tol arah masuk (entry) untuk dipakai menjadi gardu tol arah keluar (exit), dengan tetap menyediakan minimal 1 (satu) gardu tol arah masuk (entry). Hal lain adalah diperlukan kesadaran pengguna kendaraan dalam memastikan kartu tol elektronik selalu terisi saldo yang cukup.
\end{abstract}

Kata kunci : kartu tol elektronik, gerbang tol, tingkat pelayanan

\section{PENDAHULUAN}

\section{Latar Belakang}

Jalan tol saat ini memiliki peran yang penting dalam mengefisienkan waktu tempuh perjalanan kendaraan roda 4 (empat) atau lebih dari suatu kota ke kota lain. Sistem pembayaran tol juga ikut berkembang seiring bertambahnya jumlah kendaraan yang melewati jalan tol. Kartu tol elektronik menjadi satu-satunya metode pembayaran yang digunakan di semua gardu tol. Semua golongan kendaraan melakukan transaksi pembayaran tol menggunakan kartu tol elektronik. Mengenai efektifitas penggunaan kartu ini untuk semua jenis golongan kendaraan akan menjadi topik penelitian ini.

Metode penelitian yang digunakan adalah dengan melakukan wawancara dan survai lapangan. Hasil dari metode penelitian yang dilakukan tersebut akan dianalisa untuk mengetahui tingkat kinerja pelayanan gardu tol dengan menggunakan metode pembayaran kartu tol elektronik.

Penelitian ini diharapkan dapat menghasilkan tingkat pelayanan gardu tol dengan menggunakan metode pembayaran kartu tol elektronik untuk semua jenis golongan kendaraan.

Perumusan Masalah

Berdasarkan uraian di atas, permasalahannya adalah untuk mengetahui bagaimana efektifitas penggunaan kartu tol elektronik (e-toll card) untuk semua jenis golongan kendaraan.

\section{Ruang Lingkup Pembahasan}


Kegiatan Penelitian Dosen Universitas Semarang dengan judul "Tinjauan Metode Pembayaran Kartu Tol Elektronik (Lokasi Di Gerbang Tol Banyumanik, Jalan Tol Semarang-Solo)" berlokasi di Gerbang Tol Banyumanik yang dikelola oleh PT. Trans Marga Jawa Tengah.

Fokus dari penelitian ini adalah untuk mengetahui tingkat pelayanan kendaraan di gerbang tol Banyumanik serta bagaimanakah peran operator gerbang tol setelah diterapkannya kebijakan Pemerintah yang bekerjasama dengan Badan Usaha Pengelola Jalan Tol melakukan program pemberlakuan kartu tol elektronik (e-toll card) sebagai alat transaksi pembayaran tarif jalan tol pada semua gerbang tol yang ada di Indonesia pada Oktober 2017.

\section{TINJAUAN PUSTAKA}

\section{Pengertian Jalan Tol}

Peraturan Pemerintah Republik Indonesia Nomor 15 Tahun 2005 tentang Jalan Tol, dalam Pasal 1 menyebutkan pengertian jalan umum adalah jalan yang diperuntukkan bagi lalu lintas umum. Jalan tol adalah jalan umum yang merupakan bagian sistem jaringan jalan dan sebagai jalan nasional yang penggunanya diwajibkan membayar tol. Tol adalah sejumlah uang tertentu yang dibayarkan untuk penggunaan jalan tol.

\section{Pengertian Gerbang Tol}

Bangunan atau fasilitas dimana tol dikumpulkan disebut sebagai pintu tol, rumah tol, plaza tol, atau di Indonesia lebih dikenal sebagai gerbang tol.

Gerbang tol atau pintu tol adalah tempat pelayanan transaksi tol bagi pemakai tol yang terdiri dari beberapa gardu dan sarana kelengkapan lainnya.

\section{Sistem Pengumpulan Tol}

Pengumpulan tol dapat dilakukan dengan sistem tertutup, sistem terbuka, dan sistem jalan terbuka, dengan memperhatikan kepentingan pengguna dan efisiensi pengoperasian jalan tol serta kelancaran lalu lintas. Dalam Pasal 39 Peraturan Pemerintah Nomor 15 tahun 2005 Tentang Jalan Tol, pengertian sistem pengumpulan tol adalah sebagai berikut :

a. Sistem Tertutup, adalah sistem pengumpulan tol yang kepada penggunanya diwajibkan mengambil tanda masuk pada gerbang masuk dan membayar tol pada gerbang keluar.

b. Sistem Terbuka, adalah sistem pengumpulan tol yang kepada penggunanya diwajibkan membayar tol pada saat melewati gerbang masuk atau gerbang keluar.

c. Sistem Jalan Terbuka, adalah tidak adanya gerbang tol, yang ada hanya pengumpulan tol di pintu masuk atau keluar, atau di lokasi strategis pada jalur utama jalan.

\section{Sistem Antrian}

Sistem antrian ini dimulai dari masuknya unit-unit pelanggan ke dalam suatu wilayah/kawasan antrian (dalam hal ini kawasan gerbang tol), kemudian unit-unit pelanggan tersebut mengantri untuk menunggu giliran. Pada saat gilirannya, tiap unit pelanggan masuk ke dalam fasilitas pelayanan untuk dilayani. Setelah dilayani, tiap unit pelanggan tersebut meninggalkan fasilitas pelayanan yang berarti juga meninggalkan sistem antrian.

Ketika unit-unit pelanggan mulai memasuki sistem, mereka menganut suatu pola kedatangan (arrival pattern) tertentu. Unit-unit pelanggan tersebut mungkin datang dengan pola kedatangan yang konstan atau secara acak/random (yaitu beberapa unit pelanggan per periode tertentu). Tingkat kedatangan ini sering disimbolkan dengan $\lambda$.

Demikian pula di dalam fasilitas pelayanan. Dalam melayani para pelanggan, operator fasilitas tersebut akan mempunyai pola pelayanan (service pattern) tertentu. Pola pelayanan ini dicirikan oleh waktu pelayanan, yaitu waktu yang dibutuhkan oleh seorang operator untuk melayani seorang pelanggan.

\section{TUJUAN DAN MANFAAT PENELITIAN}

\section{Tujuan Penelitian}

Tujuan dari penelitian ini adalah sebagai berikut :

a. Untuk mengetahui tingkat pelayanan kendaraan di Gerbang Tol Banyumanik.

b. Bagaimana penggunaan kartu elektronik untuk semua golongan kendaraan.

c. Bagaimanakah peran operator pada gardu tol. 


\section{Manfaat Penelitian}

Bagi Peneliti

- Dapat mengaplikasikan teori-teori yang telah dipelajari.

- Dapat menganalisa penggunaan kartu tol elektronik (e-toll card) untuk semua jenis golongan kendaraan.

- Dapat menganalisa peran operator pada gerbang tol.

- Dapat dijadikan sebagai bahan ajar (materi perkuliahan) kepada mahasiswa.

Bagi Pengelola Jalan Tol

Sebagai sumbangan pemikiran dalam pembuatan kebijakan yang baru mengenai pelayanan gerbang tol di masa yang akan datang.

\section{METODE PENELITIAN}

Pada penelitian ini, metode pelaksanaan penelitian terlihat dalam bagan alir pada gambar berikut ini :

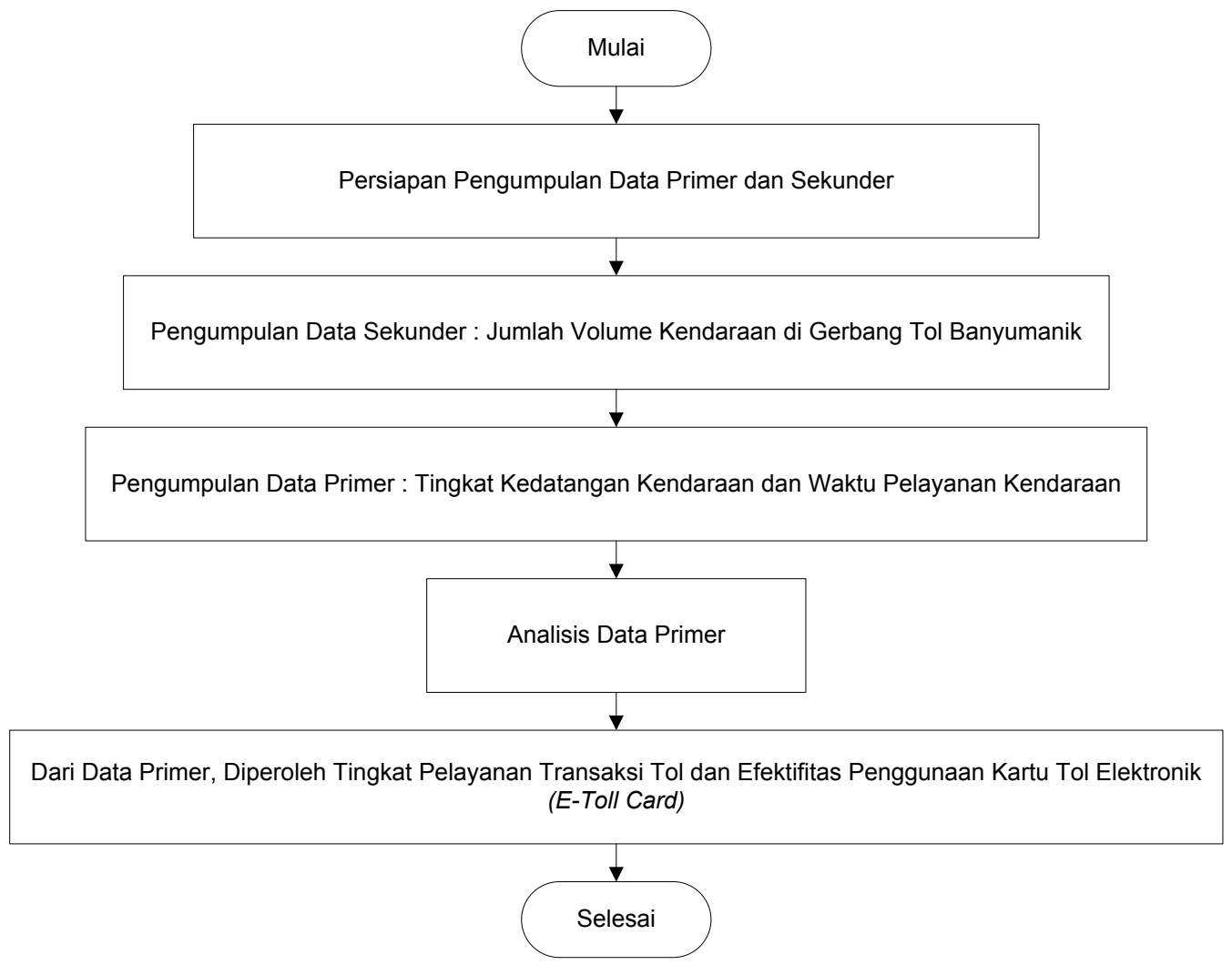

Gambar 1 Bagan Alir Penelitian

Data sekunder yang dikumpulkan diantaranya adalah data lalu lintas kendaraan yang dilayani oleh Gerbang Tol Banyumanik. Data ini dikumpulkan dari PT. Trans Marga Jawa Tengah.

Penelitian ini dilakukan pada Gerbang Tol Banyumanik arah keluar (exit). Pengumpulan data berdasarkan pada informasi PT. Trans Marga Jawa Tengah mengenai kepadatan volume lalu lintas pada hari Senin, Rabu, Jumat, Sabtu, dan Minggu, pada pagi hari pukul 07.00-08.30 WIB dan pada sore hari pukul 15.30-18.00.

\section{ANALISA PENELITIAN}

Analisa Data

Rekapitulasi data sekunder jumlah kendaraan yang melakukan pembayaran dengan tunai maupun dengan kartu tol elektronik (e-toll card) pada tanggal 5, 7, 8, 9, 10, 11, 12 Mei 2018 dapat dilihat pada tabel berikut ini. 
Tabel 1. Prosentase Pembayaran Tarif Tol Tunai dan E-Toll Card

\begin{tabular}{|c|c|c|c|c|c|c|}
\hline Tanggal & Tunai & E-Toll & Sub Total & & \% Tunai & \% E-Toll \\
\hline 5 Mei 2018 & 522 & 15970 & 16492 & & 3.17 & 96.83 \\
\hline 7 Mei 2018 & 398 & 15065 & 15463 & & 2.57 & 97.43 \\
\hline 8 Mei 2018 & 443 & 13710 & 14153 & & 3.13 & 96.87 \\
\hline 9 Mei 2018 & 471 & 15353 & 15824 & & 2.98 & 97.02 \\
\hline 10 Mei 2018 & 181 & 17556 & 17737 & & 1.02 & 98.98 \\
\hline 11 Mei 2018 & 135 & 16602 & 16737 & & 0.81 & 99.19 \\
\hline 12 Mei 2018 & 220 & 18044 & 18264 & & 1.20 & 98.80 \\
\hline Jumlah & $\mathbf{2 3 7 0}$ & $\mathbf{1 1 2 3 0 0}$ & $\mathbf{1 1 4 6 7 0}$ & Rata-Rata $=$ & $\mathbf{2}$ & $\mathbf{9 8}$ \\
\hline
\end{tabular}

Sumber : Analisis Tim Peneliti, 2018

Rekapitulasi hasil survai waktu pelayanan dan analisa waktu pelayanan seperti pada tabel-tabel berikut ini :

Tabel 2. Rekapitulasi Hasil Survai Waktu Pelayanan

\begin{tabular}{|c|c|c|c|c|c|}
\hline \multirow{2}{*}{ No } & \multirow{2}{*}{ Gardu Tol } & \multicolumn{2}{|c|}{ Mulai } & \multicolumn{2}{c|}{ Selesai } \\
\cline { 3 - 6 } & & Jam & Data & Jam & Data \\
\hline 1 & 2 & $15: 36: 55$ & 702870 & $16: 53: 29$ & 703215 \\
\hline 2 & 4 & $15: 36: 00$ & 904814 & $16: 53: 07$ & 905173 \\
\hline 3 & 6 & $15: 36: 22$ & 407740 & $16: 53: 00$ & 408077 \\
\hline 4 & 8 & $15: 35: 55$ & 196649 & $16: 55: 01$ & 196948 \\
\hline 5 & 12 & $15: 35: 32$ & 73284 & $16: 52: 42$ & 73549 \\
\hline 6 & 14 & $15: 36: 44$ & 158714 & $16: 53: 46$ & 159094 \\
\hline
\end{tabular}

Sumber : Rekapitulasi Data Analisis Tim Peneliti, 2018

- Durasi pengamatan di tiap gardu diperoleh dengan cara :

Durasi Pengamatan = Jam Selesai - Jam Mulai

Hasil dari durasi pengamatan diubah ke dalam satuan detik.

- Jumlah kendaraan yang melintas di tiap gardu diperoleh dengan cara :

Jumlah Kendaraan $=$ Data Selesai - Data Mulai

- Waktu pelayanan di tiap gardu diperoleh dengan cara :

Waktu Pelayanan = Durasi Pengamatan : Jumlah Kendaraan

Tabel 3. Waktu Pelayanan Gardu Tol

\begin{tabular}{|c|c|r|r|r|}
\hline No & Gardu Tol & $\begin{array}{c}\text { Durasi Pengamatan } \\
\text { (detik) }\end{array}$ & $\begin{array}{c}\text { Jumlah } \\
\text { Kendaraan }\end{array}$ & \multicolumn{2}{|c|}{$\begin{array}{c}\text { Waktu Pelayanan } \\
\text { (detik) }\end{array}$} \\
\hline 1 & 2 & 4594 & 345 & 13.3 \\
\hline 2 & 4 & 4627 & 359 & 12.9 \\
\hline 3 & 6 & 4598 & 337 & 13.6 \\
\hline 4 & 8 & 4746 & 299 & 15.9 \\
\hline 5 & 12 & 4630 & 265 & 12.5 \\
\hline 6 & 14 & 4622 & 380 & 12.2 \\
\cline { 2 - 4 } & & Jumlah & $\mathbf{1 9 8 5}$ &
\end{tabular}

Sumber : Analisis Tim Peneliti, 2018

- Waktu Pelayanan Rata-Rata diperoleh dari penjumlahan waktu pelayanan tiap gardu dibagi dengan jumlah gardu.

$=(13 \cdot 3+12 \cdot 9+13 \cdot 6+15 \cdot 9+17 \cdot 5+12 \cdot 2) / 6$

$=14.2$ detik

- Tingkat Pelayanan Rata-Rata Gardu $(\mu)$

$=1 /$ Waktu Pelayanan Rata-Rata 
$=1 / 14.2$

$=0.07029366$ kendaraan $/$ detik

atau

$=3600 \times 14.2$

$=253.057 \approx 253$ kendaraan/jam .

- Rasio tingkat kedatangan dengan tingkat pelayanan $(\rho)$

$\rho=\frac{\lambda}{k^{*} \mu}$

Keterangan :

$\lambda=1985$ kendaraan per jam

$\mu=253$ kendaraan per jam

$k=6$ gardu

$\rho=\frac{1985}{6 * 253} \rightarrow \quad \rho=1.3$

Dengan nilai $\rho \geq 1$, maka dapat diartikan bahwa pada Gerbang Tol Banyumanik jalur keluar (exit) mengalami antrian yang cukup panjang.

Dari survai di lapangan, ada sejumlah pengguna kendaraan yang saldo kartu tol elektroniknya tidak cukup untuk membayar tol. Karena itu maka dilakukan pembayaran dengan uang tunai, yang menimbulkan antrian cukup panjang di gardu tol tersebut. Hal yang sama juga terjadi di gardugardu exit yang lain, sehingga rata-rata waktu pelayanan transaksi tol di enam gardu exit adalah 14,2 detik, dan nilai $\rho=1,3$.

\section{Target Pencapaian Luaran}

Target pencapaian luaran Penelitian Dosen Universitas Semarang dengan judul "Tinjauan Metode Pembayaran Kartu Tol Elektronik (Lokasi Di Gerbang Tol Banyumanik, Jalan Tol Semarang-Solo)" adalah sebagai berikut :

Tabel 4. Rencana Target Capaian Luaran Kegiatan Penelitian USM

\begin{tabular}{|c|l|l|}
\hline No & \multicolumn{1}{|c|}{ Jenis Luaran } & \multicolumn{1}{|c|}{ Indikator Capaian } \\
\hline 1. & Publikasi ilmiah jurnal & Reviewed* $^{*}$ \\
\hline 2. & Bahan ajar & Ada $^{* *}$ \\
\hline
\end{tabular}

Keterangan :

* Jurnal Pengembangan Rekayasa dan Teknologi Lembaga Penelitian dan Pengabdian Kepada Masyarakat (LPPM) Universitas Semarang.

** Materi bahan ajar perkuliahan pada mata kuliah "Sistem Transportasi".

\section{KESIMPULAN DAN SARAN}

\section{Kesimpulan}

Dari hasil analisis pada data lalu lintas Gerbang Tol Banyumanik tanggal 5, 7, 8, 9, 10, 11, dan 12 Mei 2018, total jumlah transaksi pembayaran menggunakan uang tunai sebesar 2.370 transaksi, sedangkan total jumlah transaksi pembayaran menggunakan kartu tol elektronik (e-toll card) sebesar 112.300 transaksi. Secara persentase diperoleh perbandingannya sebesar $2 \%$ transaksi tunai berbanding 98\% transaksi menggunakan kartu tol elektronik (e-toll card).

Untuk hasil survai waktu pelayanan kendaraan diketahui tingkat kedatangan kendaraan arah keluar (exit) sebesar 1985 kendaraan/jam, tingkat pelayanan rata-rata kendaraan di gardu arah keluar (exit) sebesar 253 kendaraan/jam, dengan jumlah gardu pelayanan sebanyak 6 gardu. Rasio tingkat kedatangan dengan tingkat pelayanan $(\rho)$ adalah 1,3 . Dengan nilai $\rho \geq 1$, gerbang tol Banyumanik arah keluar (exit) mengalami antrian yang cukup panjang. Hal ini terjadi karena ada sejumlah pengguna kendaraan yang saldo kartu tol elektroniknya tidak cukup untuk membayar 
tol, sehingga dilakukan pembayaran dengan uang tunai. Hal yang sama juga terjadi di gardu-gardu exit yang lain.

\section{Saran}

Dengan nilai rasio tingkat pelayanan gardu tol $(\rho \geq 1)$, maka dapat diartikan bahwa pada Gerbang Tol Banyumanik arah keluar (exit) mengalami antrian yang cukup panjang. Salah satu alternatif cara untuk mengurangi panjang antrian adalah dengan mengalihkan sejumlah gardu tol arah masuk (entry) untuk dipakai menjadi gardu tol arah keluar (exit), dengan tetap menyediakan minimal 1 (satu) gardu tol arah masuk (entry). Hal lain adalah diperlukan kesadaran pengguna kendaraan dalam memastikan kartu tol elektronik selalu terisi saldo yang cukup.

\section{DAFTAR PUSTAKA}

Suharyo S, 2014. Analisis Antrian Gerbang Tol Dengan Simulasi Multi Channel (Studi Kasus Gerbang Tol Tembalang, Jalan Tol Semarang, Tesis. Undip, Semarang.

Basworo S.P, \& Tri Agung M, 2004. Evaluasi Kinerja Gerbang Tol Studi Kasus Gerbang Tol Pasteur, Tugas Akhir. ITB, Bandung.

Dwipajana S.S., 2000. Optimalisasi Kapasitas Gerbang Tol Pondok Gede Timur Dengan Teori Antrian, Tesis. Undip, Semarang.

Setiadji B.H, \& Maulidani J., 1996. Optimasi Bukaan Gerbang Tol Studi Kasus Di Gerbang Tol Pasteur Jalan Tol Padalarang-Cileunyi, Tugas Akhir. ITB, Bandung.

Siagian P, 1987. Penelitian Operasional. Gunung Agung, Jakarta.

Sudrajat, H.W, 1996. Evaluasi Kemampuan Pelayanan Gerbang Tol Studi Kasus Gerbang Tol Padalarang, Tesis. ITB, Bandung.

Peraturan Pemerintah Republik Indonesia Nomor 15 Tahun 2005 tentang Jalan Tol. 